Full Length Article

\title{
Performance Assessment of Combining AquaCrop Model with Recalculating Air Temperature of Straw-mulching Maize for Estimating Evapo-transpiration and Yield
}

\author{
Ning Yang ${ }^{1,2}$, Zhanxiang Sun ${ }^{1 *}$, Muzi Zheng ${ }^{3}$, Liangshan Feng ${ }^{1}$, Lizhen Zhang ${ }^{2 *}$, Wei Bai ${ }^{1}$ and Wuyan Xiang ${ }^{1}$ \\ ${ }^{1}$ Liaoning Academy of Agricultural Sciences/Engineering Research Centre for Dryland and Water-Efficient Farming of \\ Liaoning Province, Shenyang, Liaoning 110161, China \\ ${ }^{2}$ China Agricultural University, Beijing, 100083, China \\ ${ }^{3}$ The Department of Agricultural Engineering, University of Tennessee, Knoxville, Tennessee, USA \\ *For correspondence: laasyn@163.com
}

\begin{abstract}
A water-driven AquaCrop model, constantly simulated and recommended by FAO has been a widely accepted and is a powerful tool for assessing the productivity response to crop water utilization in rain-fed farming system. We recalculated AquaCrop model's daily air temperature of straw-mulching (SM) based upon the inter-conversion effect of the cumulative soil temperature with the cumulative air temperature and the relationship between air temperature and the soil temperature of the maize(Zea mays L.) in 2014a. The straw-mulched maize compensatory coefficient ( $\mathrm{C}_{\text {SM-maize }}$ ) and air decrement of the cumulative soil temperature with the cumulative air temperature can be calculated as follows: $\mathrm{C}_{\mathrm{SM}-m a i z e}$ was -0.797 from sowing to emergence, -0.637 from emergence to the tasseling stage and 0 after harvesting in the inter-conversion process. In addition, we calibrated the $\mathrm{C}_{\mathrm{SM} \text {-maize }}$ and recalculated air temperature by using measured experimental data of the growing days the evapo-transpiration (ET) and the grain yield (GY) in 2011a. After experimental data from 2012 and $2013 \mathrm{a}$ were used to validate the developed model for simulating the canopy cover $(\mathrm{CC})$, soil water content $(\mathrm{SWC})$, GY the prediction error $\left(\mathrm{P}_{\mathrm{e}}\right)$, the coefficient of determination $\left(\mathrm{R}^{2}\right)$, the model coefficient of efficiency $(\mathrm{CE})$ the relative root mean square error $(\mathrm{RRMSE})$ and the Willmott index of agreement $(\mathrm{d})$ were used to assess the model performance. The AquaCrop along with the original and recalculating SM air temperature were measured and simulated for the values of the growing days. The ET and GY were$5 \%<\mathrm{P}_{\mathrm{e}}<5 \%, 0.01<\mathrm{RRMSE}<0.04$ and $-0.85<\mathrm{d}$ in 2011a. Further verifications were simulated and measured for the values of the SWC and $\mathrm{CC}$, which were $0.88<\mathrm{R}^{2}, 0.87<\mathrm{CE}, 0.09<\mathrm{RRMSE}<0.39$ from 2012 to 2013 respectively. The $\mathrm{P}_{\mathrm{e}}$ of the model in GY, ET and WUE was $5 \%<\mathrm{P}_{\mathrm{e}},-4 \%<\mathrm{P}_{\mathrm{e}}<4 \%$ and $\mathrm{P}_{\mathrm{e}}<7 \%$, respectively. These results indicated that the modified and recalculated SM air temperature used in the AquaCrop model was a better mechanism and application for simulating straw-mulched maize development process. Furthermore, the modeling and simulating determined that the relationship between ET and the transpiration $(\mathrm{T})$ had a significantly positive linear correlation with SM $\left(\mathrm{R}^{2}=0.94\right)$ and NM $\left(\mathrm{R}^{2}=0.94\right)$. The SM and NM highest GY response to historical rainfall were determined, respectively. Also, the precipitation use efficient (PUE) of SM was $19.4 \%$ higher than NM. Recalculating air temperature of straw-mulching was a noteworthy path toward improving the AquaCrop model for mulching and was a suitable and novel way to simulate and estimate the T, ET and GY responses to the water of developing straw-mulched maize rain-fed farming systems. (C) 2017 Friends Science Publishers
\end{abstract}

Keywords: Maize; Straw mulching; Crop model aquacrop; Crop evapotranspiration

\section{Introduction}

Straw mulching on the surface of agricultural soils was a well-established protective farming technique which reduced soil erosion increased soil water content (Huang et al., 2006) lowered soil surface temperature reduced weeds density (Hoshino et al., 2017) natural decomposition and non-pollution (Yang et al., 2015) increased yield and improved precipitation use efficiency (Edwards et al., 2000;
Gao and Li, 2005) in arid and semi-arid regions of the world. Mulched straw can increase or decrease the reflectivity of solar radiation and increase the resistance of heat and water vapor transmission. In Northwest China the winter wheat/summer maize rotation system studies showed that reduced temperature fluctuations of straw mulching were favorable to flowering grain filling of summer maize growth and increasing its yield. However, mulching maize straw reduced the wheat yield. Cooling soil temperature was

To cite this paper: Yang, N., Z. Sun, M. Zheng, L. Feng, L. Zhang, W. Bai and W. Xiang, 2017. Performance assessment of combining aquacrop model with recalculating air temperature of straw-mulching maize for estimating evapo-transpiration and yield. Int. J. Agric. Biol., 19: 1156-1164 
mainly unfavorable to crop emergence during the seeding stage in spring (Dong et al., 2008). Water and thermal dynamics mainly influenced efficient water saving and crop yield uncertainty of straw mulching at different regions (Acharya et al., 2005).

Developing the differential equation mulching models of energy distribution and evapo-transpiration focused on the coupling process between soil water and thermal change (Li et al., 2000; Wu et al., 2000), which ignored the verification among the crop growth period, water use and yield formation process. Furthermore, these differential model equations demanded many more input parameters and complex calculating. They were also difficult to run under field conditions that had limited model application ( $\mathrm{Li}$ et al., 2000). With increasing straw mulched farming areas in sandy and semi-arid regions in China, we need to develop suitable methods and crop model responses to crop growth water and yield in order to estimate the evapo-transpiration and yield of straw mulching in protective farming systems.

Crop models are powerful as decision support tools for productivity response to crop water utilization (Steduto et al., 2009). However, most models are complicated and require some skills for calibration (Heng et al., 2009). For instance the DASST (Timsina et al., 2008; Mubeen et al., 2013) and APSIM (McCown et al., 1996) models require many parameters and the CropSyst (Stöckle et al., 2003) and WOFOST (Diepen et al., 2007) models are relatively complicated (Todorovic et al., 2009). These problems partly limited the development and application of these models. The AquaCrop model (www.fao.org/nr/water/aquacrop.html) simulates yields for crops as a function of water consumption and as a waterdriven model (Du et al., 2011), which is an attempt to develop an accurate, simple, versatile and robust userfriendly model. It could be used in determining the optimal water application in field crops (Abedinpour et al., 2012; Wang et al., 2013) and economic crops (Farahani et al., 2009; Joost et al., 2013) under rain and several irrigation conditions in climatic and agricultural policy scenarios (Margarita and Elias, 2012). However, mulching and watersaving cultivation may partially be neglected in the AquaCrop model's design. Although the straw-mulched parameters appeared in the crop management module of the AquaCrop, it did not explain the straw-mulched crop simulation of the water-yield mechanism and the process, which limited the further application of straw mulching on the AquaCrop model. The objectives of this study were (i) to illustrate the air and soil temperature and develop the method of recalculating air temperature of the strawmulched maize, as well as (ii) calibrating and validating the AquaCrop by recalculating the air temperature of the strawmulched maize in order to simulate canopy cover, soil water content and yield through the use of experimental data. It was also used (iii) to simulate and estimate crop evapotranspiration, transpiration and the yield effect of the straw- mulched maize. In order to achieve these objectives, we first calibrated and validated by combining the AquaCrop model with the recalculation of the air temperature of the strawmulched maize. Then we simulated the response function between the crop evapo-transpiration (ET) and transpiration (T), as well as between the minimum precipitation and the maximum rainfed yield. Then we assessed the developed AquaCrop model in sandy and semi-arid regions and improved the AquaCrop's theoretical basis and technical support.

\section{Materials and Methods}

\section{Materials and Experimental Designs}

The field experiments were conducted in 2011 to 2014 at the Fuxin agricultural experimental station in the Liaoning Province of China $\left(42^{\circ} 09^{\prime} \mathrm{N}, 121^{\circ} 46^{\prime} \mathrm{E}\right.$ and $213 \mathrm{~m}$ above sea level). The common regional cropping system is one crop per year. Rain-fed agriculture is the dominant production system. The study area is a semi-arid climate with an average annuls rainfall of $430 \mathrm{~mm}$ and the rainfall is relatively deficit during the crop growing season. The physical and chemical characteristics of the field experiments' soil are given in Table 1. In this experiment, we applied two treatments to the maize plots including control with non-mulch (NM, Fig. 1a) and straw mulching (SM, Fig. 1b) as well as cropping. The two treatments involved alternation wide and narrow row spacing of $60 \mathrm{~cm}$ and $40 \mathrm{~cm}$ and were applied to $60 \mathrm{~m}^{2}(10 \mathrm{~m} * 6 \mathrm{~m})$ plots arranged in a completely randomized block design with three replicates. After ridging the treatment plots the $300 \mathrm{~kg}$ $\mathrm{hm}^{-2}$ NPK compound-fertilizer (N15\%P15\%K15\%) was broadcasted over the soil surface as a base fertilizer the soil was then ploughed to imbed the fertilizer into the subsurface. The maize was planted $5 \mathrm{~cm}$ deep at a density of 60,000 plants $\mathrm{hm}^{-2}$ after mulching straw in each plot on May $1^{\text {st }}$. The water supply for each treatment came solely from natural rainfall. Additional nitrogen in the form of urea $(\mathrm{N}$ $46 \%$ ) was applied using a hole-so wing machine in the furrows at rates of $300 \mathrm{~kg} \mathrm{hm}^{-2}$ during the jointing and tasselling stages.

\section{Soil Temperature Monitoring}

Decagon-5TM (made in USA) sensors were embedded in the soil at a $5 \mathrm{~cm}$ depth between plant rows in order to measure soil temperature. The daily soil temperature of NM and SM were recorded automatically for EM50 (Decagon) each hour.

\section{Test Determination and Model Validation}

Soil water Storage and Crop Evapo-transpiration: In each maize-growing season, through the use of the drying method we determined the 2011-2013 key growth stage in 
Table 1: The physical and chemical characteristics of $0-50 \mathrm{~cm}$ depth soil

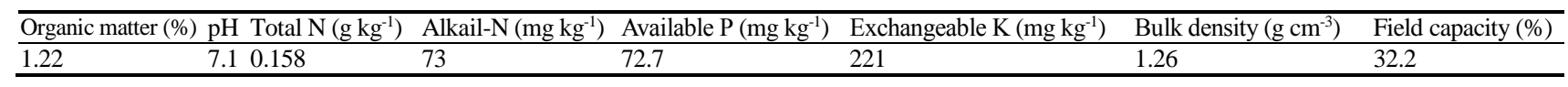
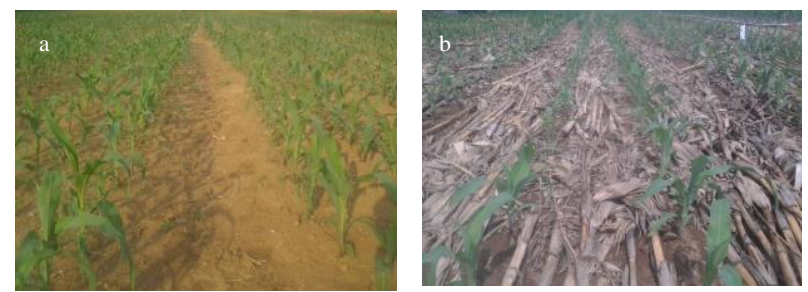

Fig. 1: The different experimental treatments for rain-fed maize production at the station, (a) non-mulched (NM); and (b) straw-mulching (SM)

the maize (from sowing, seedling, jointing, pumping heading stage and grain filling stage, maturity and harvest). Every 2 weeks we determined that the $120 \mathrm{~cm}$ soil water content of $0-40 \mathrm{~cm}$ soil layer was $10 \mathrm{~cm}$ a level. The $40-120 \mathrm{~cm}$ soil layer was $20 \mathrm{~cm}$ a level and the crop water consumption (ET) was calculated by the farmland water balance method.

$$
\begin{gathered}
W=a \times b \times h \times 10 / 100 \\
E T=I R+P \pm \Delta W
\end{gathered}
$$

Where $a$ was soil bulk density $\left(\mathrm{g} \mathrm{cm}^{-3}\right), b$ was soil gravimetric water content $\left(\mathrm{cm}^{-3} \mathrm{~cm}^{-3}\right), h$ was soil depth $(\mathrm{cm})$, $P$ was the total precipitation $(\mathrm{mm})$ and SWS was the change in soil water storage $(\mathrm{mm})$ between the planting and harvesting stages. Change in soil water storage $(\Delta \mathrm{W})$ in the 0-200 cm profile was calculated using the formula: $\Delta W=W_{\mathrm{t} 2}-W_{\mathrm{t} 1}$, where $W_{\mathrm{t} 1}$ and $W_{\mathrm{t} 2}$ were the soil water storage in the $0-200 \mathrm{~cm}$ soil profile at times $t_{1}$ and $t_{2}$, respectively. $I R$ was the Irrigation amount in a period of time $(\mathrm{mm}) ; \mathrm{P}$ was precipitation during the period of time $(\mathrm{mm})$.

\section{Leaf Area Index (LAI) and Canopy Cover (CC)}

The area of each of the fresh leaves of the sampled plants was determined immediately after harvesting them for each leaf. The length and maximum width were measured and the leaf area was estimated using the following equation: area =length $\times$ width $\times 0.75$. The leaf area index was calculated using the following equation (Zhang et al., 2013).

$$
\mathrm{LAI}=[S 1 \times(W 1+W 2) / W 1 \times S 2]
$$

And the canopy cover was calculated using the following equation (Hsiao et al., 2009).

$$
C C=1.005[1-\exp (-0.6 \mathrm{LAI})]^{1.2}
$$

Where, $S 1$ and $S 2$ was the measured leaf area $\left(\mathrm{m}^{2}\right)$ and land area $\left(\mathrm{m}^{2}\right)$, respectively. $W 1$ is the dry weight of the 100 leaves and $W 2$ is weight of the rest of the leaves from each sample. $S 1$ was the leaf area $\left(\mathrm{m}^{2}\right) . C C$ was canopy cover $(\%)$.

\section{Yield and Water-use Efficiency}

At maize maturity, the sampled plants grain yield was measured for all plants selected from a $10 \mathrm{~m}^{2}$ area in each plot. The grain yield was determined based on the average of three plot replicates and all samples were dried to a constant weight oven at $75^{\circ} \mathrm{C}$. All mass values are expressed in relation to the dry weight.

$$
\begin{gathered}
P U E=G Y / P \\
W U E=G Y / E T
\end{gathered}
$$

Where, precipitations use efficiency and the wateruse efficiency $\left(\mathrm{kg} \mathrm{m}^{-3}\right)$ was calculated as the grain yield $\left(\mathrm{GY}, \mathrm{kg} \mathrm{hm}^{-2}\right)$ divided by the total ET (mm) over the growing.

\section{Improvement of Air Temperature Calculation Path and Method}

According to the theory of effective cumulative temperature of the crop growth and development (Zhang et al., 2003; Zhang et al., 2008) we improved the AquaCrop model's air temperature of straw mulching by using the inter-conversion effect of the cumulative soil temperature with the cumulative air temperature. Improved and calculated paths and methods are shown in Fig. 2.

Where $\mathrm{T}_{\text {air-max }}$ and $\mathrm{T}_{\text {soil-max }}$ is the daily maximum air temperature $\left(\mathrm{T}_{\text {air }},{ }^{\circ} \mathrm{C}\right)$ and the daily maximum soil temperature $\left(\mathrm{T}_{\text {soil }},{ }^{\circ} \mathrm{C}\right), \mathrm{T}_{\text {air-min }}$ and $\mathrm{T}_{\text {soil-min }}$ is the daily minimum $\mathrm{T}_{\text {air }}\left({ }^{\circ} \mathrm{C}\right)$ and the daily minimum $\mathrm{T}_{\text {soil }}\left({ }^{\circ} \mathrm{C}\right)$ is the daily minimum $\mathrm{T}_{\text {air }} \cdot\left({ }^{\circ} \mathrm{C}_{\mathrm{r}}\right) . \mathrm{T}_{\text {base }}$ is the biology initial temperature (Maize's $\mathrm{T}_{\text {base }}$ is $8^{\circ} \mathrm{C}$ in the AquaCrop model). $\mathrm{TT}$ is the effective cumulative temperature $\left({ }^{\circ} \mathrm{C}\right), \mathrm{TT}_{\text {air-NM }}$ is the air cumulative temperature of non-mulch $\left({ }^{\circ} \mathrm{C}\right)$ and $\mathrm{TT}_{\text {air- }}$ SM is the air cumulative temperature of straw mulching $\left({ }^{\circ} \mathrm{C}\right)$. $\mathrm{TT}_{\text {soil-SM }}$ is the soil cumulative temperature of strawmulching $\left({ }^{\circ} \mathrm{C}\right), \mathrm{TT}_{\text {soil-NM }}$ is the soil cumulative temperature of non-mulch $\left({ }^{\circ} \mathrm{C}\right)$, and $\mathrm{TT}_{\text {soil-NM }}$ is the soil cumulative temperature of non-mulching ${ }^{\circ} \mathrm{C}, \mathrm{T}_{\text {soil-SM }}$ is the daily soil temperature of straw mulching in $5 \mathrm{~cm}$ depth $\left({ }^{\circ} \mathrm{C}\right)$; $\mathrm{T}_{\text {soil-NM }}$ is the daily soil temperature of non-mulching in $5 \mathrm{~cm}$ depth $\left({ }^{\circ} \mathrm{C}\right) ; \mathrm{C}_{\mathrm{SM}^{-} \text {maize }}$ is the compensatory coefficient $(\mathrm{C})$ response to air decrement of the cumulative soil temperature with the cumulative air temperature of the straw-mulched maize (Xiao et al., 1998); $\Delta \mathrm{T}$ is the change response to $\mathrm{C}_{\mathrm{SM}}$ maize; $\mathrm{T}_{\text {air-NM }}$ is the air temperature of non-mulch $\left({ }^{\circ} \mathrm{C}\right)$; $\mathrm{T}_{\text {air-SM }}$ is the air temperature of straw mulching in the AquaCrop model $\left({ }^{\circ} \mathrm{C}\right)$. 


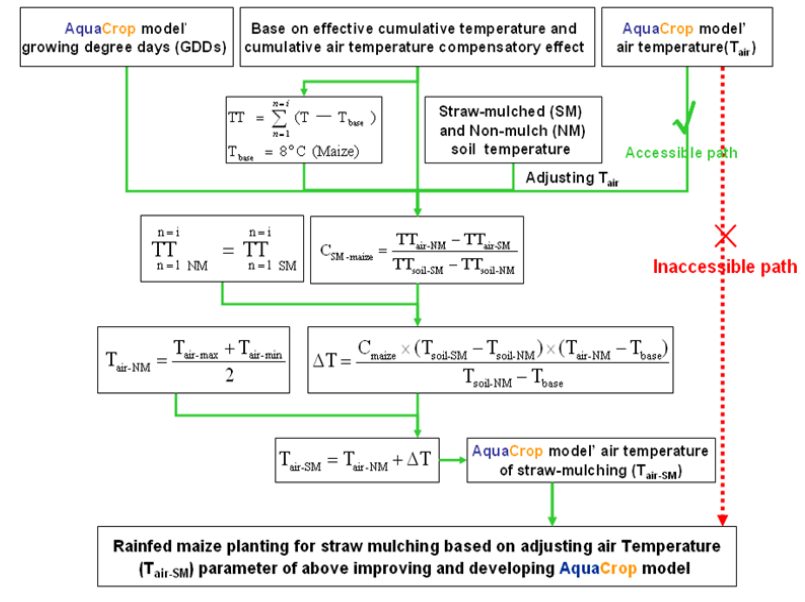

Fig. 2: Diagram of recalculating air temperature path of straw-mulching maize for running Aqua Crop model

\section{AquaCrop Parameters}

The parameters not included in the Table 2 were kept at their default valued of AquaCrop (Todorovic et al., 2009).

\section{AquaCrop Model Calibration and Validation}

The calibration and validation of the AquaCrop model initial and adjusted parameter for SM and NM that affects the growing days, SWC, CC and ET throughout the growing period, GY and WUE at harvest were assessed by comparing the measured and simulated results using statistical parameters i.e. coefficient of determination $\left(\mathrm{R}^{2}\right)$, relative root mean square error (RRMSE), Nash-Sutcliffe efficiency (CE) and the index of agreement (d) (Nash and Sutcliffe, 1970; Willmott et al., 1985). Model $\mathrm{R}^{2}$ and $\mathrm{CE}$ approaching one and $\mathrm{P}_{\mathrm{e}}$, RRMSE and d close to zero were indicators for better model performance. SPSS and Excel formed data analysis and mapping soft.

\section{Results}

\section{The Relationship between air Temperature and Soil Temperature of Straw Mulched}

Compared to no mulching, maize straw mulching reduced the average $5 \mathrm{~cm}$ depth soil temperature $2.8^{\circ} \mathrm{C}$ before the tasseling stage in the Liaoning northwest region (Fig. 3). The effects of the decrease in soil temperature began to weaken and neglect gradually, while the maximum canopy cover had developed from the tasseling stage. The physiological growth days of the straw-mulched maize was about 10 days longer than the no-mulching maize, because the effective cumulative temperature of the straw-mulched maize was insufficient.
Table 2: Input parameters of crop and management parameters used in AquaCrop model

\begin{tabular}{|c|c|c|c|}
\hline Parameter & Initial value & Adjusted value & Unit \\
\hline Air temperature & $\mathrm{T}_{\text {air }}$ & $\mathrm{T}_{\text {air-SM }}$ & ${ }^{\circ} \mathrm{C}$ \\
\hline $\begin{array}{l}\text { Growing degree days (GDD) t } \\
\text { emergence }\end{array}$ & 80 & 108 & ${ }^{\circ} \mathrm{Cd}$ \\
\hline$G D D$ to maximum canopy cover & 705 & 730 & ${ }^{\circ} \mathrm{Cd}$ \\
\hline$G D D$ to maximum rooting depth & 1409 & 1465 & ${ }^{\circ} \mathrm{Cd}$ \\
\hline$G D D$ to start of canopy senescence & 1400 & 1582 & ${ }^{\circ} \mathrm{Cd}$ \\
\hline$G D D$ to maturity & 1700 & 1811 & ${ }^{\circ} \mathrm{Cd}$ \\
\hline$G D D$ to flowering & 880 & 961 & ${ }^{\circ} \mathrm{Cd}$ \\
\hline$G D D$ Length building up HI & 750 & 831 & ${ }^{\circ} \mathrm{Cd}$ \\
\hline$G D D$ Duration of flowering & 180 & 187 & ${ }^{\circ} \mathrm{Cd}$ \\
\hline Maximum rooting depth $\left(Z_{x}\right)$ & 2.3 & 1.2 & $\mathrm{~m}$ \\
\hline Crop coefficient $\left(K_{\mathrm{cb}}\right)$ & 1.03 & 1.05 & - \\
\hline Harvest Index $(H I)$ & 48 & 45 & $\%$ \\
\hline Type of surface mulches & - & $\begin{array}{l}\text { Organic } \\
\text { materials }\end{array}$ & - \\
\hline Percentage of soil surface covered & - & 100 & $\%$ \\
\hline
\end{tabular}

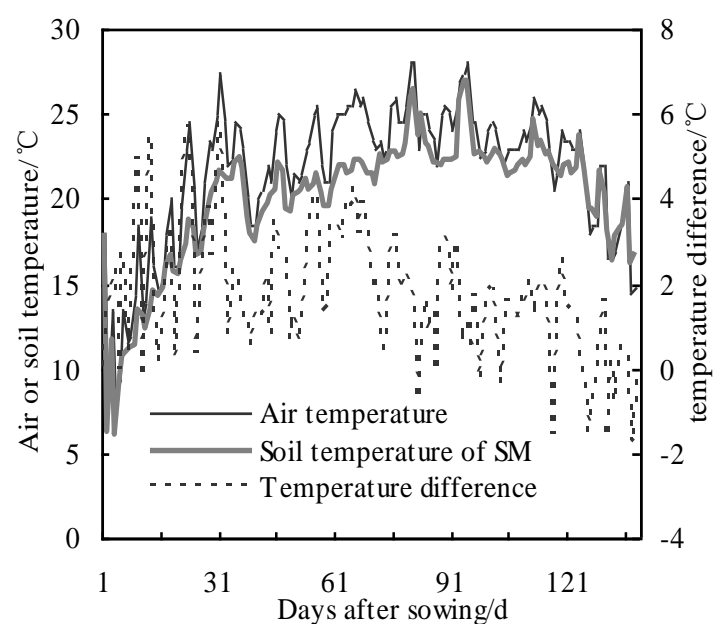

Fig. 3: Mean daily air temperature and soil temperature (in $5 \mathrm{~cm}$ depth) in $\mathrm{SM}$ and $\mathrm{NM}$ during growth period season in 2014

The significantly linear relationship and equation between $5 \mathrm{~cm}$ depth soil temperature of the strawmulched maize and air temperature were shown in Fig. 4, spanning from emergency to maximum canopy cover.

\section{The Conversion Coefficient Calculation of Soil Temperature to air Temperature}

A coefficient of the conversion of the air accumulation temperature to the soil accumulation temperature $\left(\mathrm{T}_{\text {air }}\right)$ was calculated with a method shown in Fig. 2. Furthermore, the key $\mathrm{C}_{\text {SM-maize }}$ that was between the sowing and the seeding and the seeding and the tasselling was -0.797 and -0.637 respectively. This was because the straw mulching decreased the surface soil temperature (Table 3 ). $\mathrm{T}_{\text {air-NM }}$ with the addition of air decrement ( $\square \mathrm{T}$ ) formed a new file (*.tmp) and input to AquaCrop climate module. 
Table 3: Coefficient representing on soil temperature to air temperature of straw mulching

\begin{tabular}{llllll}
\hline Growing stage & 2011 & 2012 & 2013 & Average & CV \\
\hline Sowing to emergency & -0.807 & -0.778 & -0.806 & -0.797 & 0.02 \\
Emergency to tasseling & -0.671 & -0.601 & -0.639 & -0.637 & 0.03 \\
\hline
\end{tabular}

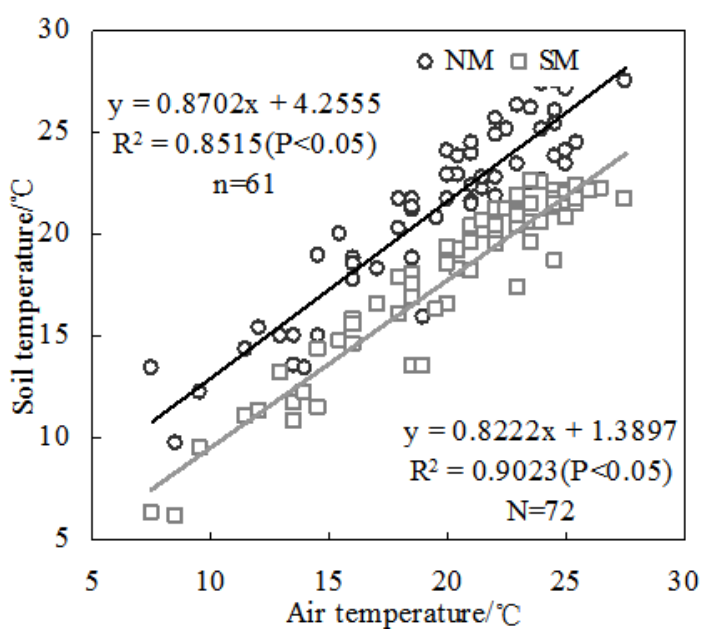

Fig. 4: The relationship between air temperature and soil temperature (in $5 \mathrm{~cm}$ depth) of $\mathrm{SM}$ and $\mathrm{NM}$ from emergency to maximum canopy cover

Finally, the temperature of the climatic data and the strawmulching air temperature of the maize $\left(\mathrm{T}_{\text {air-SM}}\right)$ can be generalized and inputted into the AquaCrop model without adjusting the AquaCrop model intrinsic programming system.

Calibration of AquaCrop Model for Recalculating the air Temperature of Straw Mulching

The calibrated original parameters and adjusted parameters (recalculating air temperatures) of the maize with and without straw mulching in sandy and semi-arid region (Table 4) in 2011a. The main differences that were considered between the two air temperatures $\left(\mathrm{T}_{\text {air-NM }}\right.$ and $\mathrm{T}_{\text {air-SM) }}$ are the growing day $\mathrm{ET}_{\mathrm{c}}$ and $\mathrm{GY}$ (due to the difference in physiological development time) with the AquaCrop simulation. The average $\mathrm{P}_{\mathrm{e}}(0.03$ to -0.01$)$, RRMSE (0.10 to 0.03$)$ and $d(0.60$ to 0.94$)$ between the simulated and measured data were obviously improved by the AquaCrop with adjusted parameters, indicating the goodness-fit estimation of the growing day $\mathrm{ET}_{\mathrm{c}}$ and GY of straw mulching for the maize of the AquaCrop model with the calibrated adjusting parameters in sandy and semi-arid region.

\section{Verification of Soil Water Content and Canopy Cover}

Soil moisture content (SWC) and green canopy cover (CC) is the main parameter of the AquaCrop model. SWC is the vital component of the soil water balance of the AquaCrop model. CC is positively correlated with the crop leaf area index (LAI). For validation two-year field observations in sandy and semi-arid region were considered. The validation that ran with the calibrated AquaCrop (with adjusting parameters) gave good results for the simulated SWC and $\mathrm{CC}$ of the maize (average $\mathrm{R}^{2}=0.90$; average $\mathrm{RRESM}=0.25$;and average $\mathrm{CE}=0.88$ ). Also, for the evolution of SWC and CC throughout the maize cycle (Fig. 5; Fig. 6), respectively acceptable precision was reached. Furthermore, this is an indication of the satisfactory estimation of the SWC and CC of the AquaCrop model. The AquaCrop model with recalculating $\mathrm{T}_{\text {air-SM }}$ can accurately simulate the dynamic of the SWC and CC of the strawmulched maize in sandy and semi-arid regions.

\section{The Verification of Evapotranspiration, Yield and WUE and Simulation of Transpiration and Evaporation}

Straw mulching (SM) maize increased the SWC, reduced the soil evaporation (E) as well as increased the maize transpiration (T) and improved the GY and WUE (Wang et al., 2014). For further validation and estimation a two-year experimental field was taken into account. The validation that ran with the calibrated AquaCrop (with adjusting parameters) gave satisfactory results for the simulated GY, ET and WUE of the maize (GY and ET average $\mathrm{P}_{\mathrm{e}}< \pm 5 \%$, ) (Table 5). However, there is no easy way to distinguish between $\mathrm{E}$ and $\mathrm{T}$. Based on the calibrated AquaCrop model approach, soil $\mathrm{E}$ and maize $\mathrm{T}$ can be simulated and estimated, respectively. Compared with NM, the strawmulched maize reduced the average soil evaporation of 45.55 $\mathrm{mm}$. The maize transpiration increased to an average of 55.1 $\mathrm{mm}$ over a two-year period in sandy and semi-arid regions.

\section{Effect of Straw Mulching on Evapotranspiration and Yield by Simulating of AquaCrop Model}

Base on the calibrated AquaCrop model approach and the multi-year meteorological data, ET, T and GY were simulated and given a regression analysis. The regression analysis determined the relationship between ET and T and the relationship between annual precipitation and grain yield with and without the straw-mulched maize in the growing season from 1970 to 2013a. Both ET and T with and without the straw-mulched maize had a significantly positive correlation $(\mathrm{P}<0.05)$ (Fig. 7). The slope of NM and SM was similar to 0.94 and the SM linear intercept was 31.68 higher than NM. Thus, the crop evapotranspiration of the straw-mulched maize can be accurately estimated with soil evaporation (E) in sandy and semi-arid regions. Furthermore, there was a quadratic regression analysis, which determined the relationship between multi-year growing season precipitations and rain-fed GY. Both SM and NM had a significantly positive correlation $(\mathrm{P}<$ 0.05 ) (Fig. 8). The maximum grain yields for both the SM and NM response to precipitation and PUE was $503.6 \mathrm{~mm}$, $1.60 \mathrm{~kg} \mathrm{~m}^{-3}$ and $556.1 \mathrm{~mm}, 1.34 \mathrm{~kg} \mathrm{~m}^{-3}$, respectively. This 
AquaCrop Model for Estimation of Evapo-transpiration and Yield in Maize / Int. J. Agric. Biol., Vol. 19, No. 5, 2017

Table 4: Calibration results of growing days, ET and grain yield of maize under straw mulching in 2011

\begin{tabular}{|c|c|c|c|c|c|c|c|c|c|c|}
\hline \multirow[t]{2}{*}{ Parameters } & \multirow[t]{2}{*}{ Treatment } & \multicolumn{2}{|c|}{ Simulated } & \multirow[t]{2}{*}{ Measured } & \multicolumn{2}{|c|}{$\mathrm{P}_{\mathrm{e}}$} & \multicolumn{2}{|c|}{ RRMSE } & \multicolumn{2}{|r|}{ d } \\
\hline & & $\overline{T_{\text {air }}}$ & $\mathrm{T}_{\text {sm-maize }}$ & & $\overline{T_{\text {air }}}$ & $\mathrm{T}_{\text {sm-maize }}$ & $\mathrm{T}_{\text {air }}$ & $\mathrm{T}_{\text {sm-maize }}$ & $\mathrm{T}_{\text {air }}$ & $\mathrm{T}_{\mathrm{sm}-\mathrm{maize}}$ \\
\hline Growing days & $\begin{array}{l}\text { NM } \\
\text { SM }\end{array}$ & $\begin{array}{l}127 \\
138\end{array}$ & $\begin{array}{l}138 \\
152\end{array}$ & $\begin{array}{l}139 \mathrm{~b} \\
153 \mathrm{a}\end{array}$ & $\begin{array}{l}-0.09 \\
-0.10\end{array}$ & $\begin{array}{l}-0.01 \\
-0.01\end{array}$ & 0.09 & 0.01 & 0.62 & 0.99 \\
\hline $\mathrm{ET}_{\mathrm{c}}$ & NM & 378.9 & 366.4 & $383.5 \pm 21.3 \mathrm{~b}$ & -0.01 & -0.04 & 0.06 & 0.04 & 0.65 & 0.85 \\
\hline $\mathrm{mm}$ & SM & 365.8 & 387.4 & $397.5 \pm 22.5 \mathrm{a}$ & -0.08 & -0.03 & & & & \\
\hline GY & NM & 10706 & 8374 & $8596 \pm 287.2 \mathrm{~b}$ & 0.25 & -0.03 & 0.16 & 0.03 & 0.52 & 0.97 \\
\hline $\mathrm{kghm}^{-2}$ & SM & 11743 & 10535 & $9987 \pm 302.4 \mathrm{a}$ & 0.18 & 0.05 & & & & \\
\hline Average & & - & - & - & 0.03 & -0.01 & 0.10 & 0.03 & 0.60 & 0.94 \\
\hline
\end{tabular}

Table 5: Measured the grain yield and crop evapotranspiration, as well as simulated transpiration and evaporation of straw mulch and non-mulch from 2012 and 2013

\begin{tabular}{|c|c|c|c|c|c|c|c|c|c|c|c|c|}
\hline \multirow[t]{2}{*}{ Year } & \multirow[t]{2}{*}{ Tre. } & \multicolumn{2}{|c|}{ GY $\left(\mathrm{kg} \mathrm{ha}^{-1}\right)$} & \multirow[t]{2}{*}{$\mathrm{P}_{\mathrm{e}} \pm \%$} & \multicolumn{2}{|c|}{ ET (mm) } & \multirow[t]{2}{*}{$\mathrm{P}_{\mathrm{e}} \pm \%$} & \multicolumn{2}{|c|}{ WUE $\left(\mathrm{kg} \mathrm{m}^{-3}\right)$} & \multirow[t]{2}{*}{$\mathrm{P}_{\mathrm{e}} \pm \%$} & \multirow{2}{*}{$\frac{\mathrm{T}(\mathrm{mm})}{\mathrm{Me} .}$} & \multirow{2}{*}{$\begin{array}{l}\text { E (mm) } \\
\text { Si. }\end{array}$} \\
\hline & & Me. & Si. & & Me. & Si. & & Me. & Si. & & & \\
\hline \multirow[t]{2}{*}{2012} & NM & $11624 \pm 321.5 b$ & 11738 & 4.02 & $452.2 \pm 20.1 \mathrm{a}$ & 443.1 & -2.01 & $2.50 \mathrm{a}$ & 2.66 & 6.59 & 331.4 & 111.7 \\
\hline & SM & $12015 \pm 357.4 a$ & 12109 & 3.19 & $455.4 \pm 18.9 \mathrm{a}$ & 446.8 & -1.89 & $2.58 \mathrm{a}$ & 2.71 & 5.17 & 370.3 & 76.2 \\
\hline 2013 & SM & $9975 \pm 275.3 \mathrm{a}$ & 9901 & 0.77 & $385.3 \mathrm{a} \pm 18.5 \mathrm{a}$ & 385.6 & 3.88 & $2.65 \mathrm{a}$ & 2.57 & -2.90 & 315.1 & 70.5 \\
\hline
\end{tabular}

Note: $\mathrm{GY}=$ Grain yield; $\mathrm{ET}=$ crop evapotranspiration; WUE=Water use efficiency; $\mathrm{T}=$ Transpiration; $\mathrm{E}=$ Evaporation
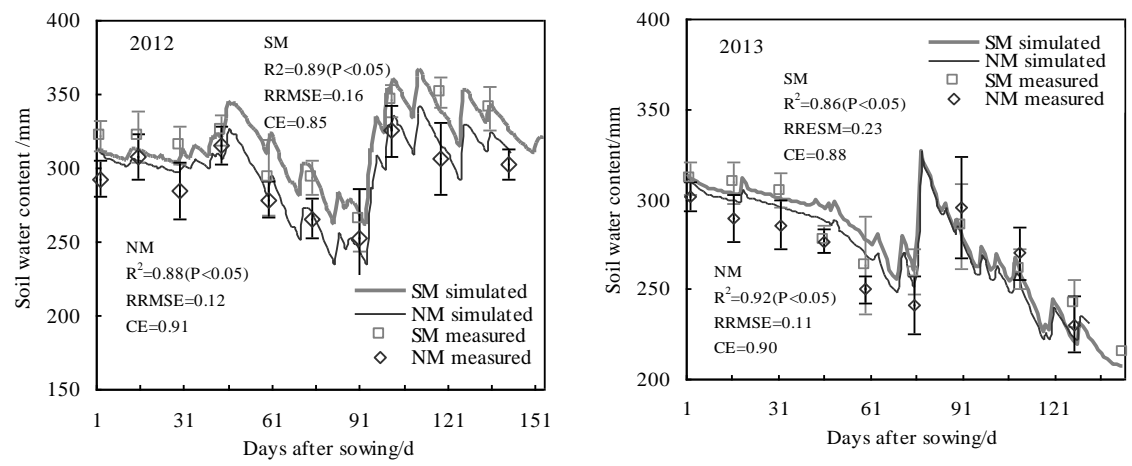

Fig. 5: Simulated and measured total soil water content of non-mulching in $1.2 \mathrm{~m}$ depth root zone from 2012 to 2013
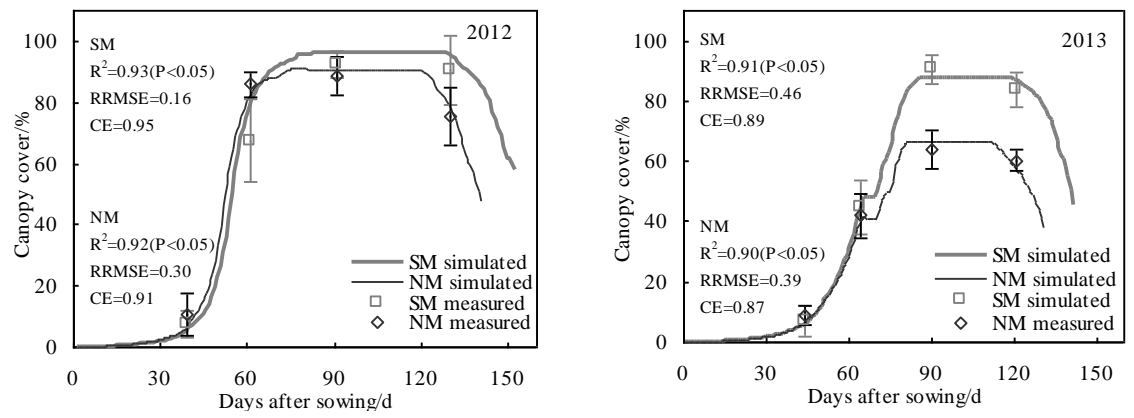

Fig. 6: Simulated and calculated canopy cover for maize non-mulching from 2012 to 2013

result was similar to the Weibei region straw-mulched maize of the Shanxi province of China (Cai et al., 2011). This technique of double conservation tillage and mulch with maize straw may sustain high PUE of the maize yield compared to no-mulching management in rain-fed regions.

\section{Discussion}

Straw mulching is one of vital conservation tillage technology in sandy and semi-arid area. The increased yield and water use efficiency (WUE) with straw mulching is largely due to improved soil water storage (Huang et al., 2006) reduced soil bulk density (Hassan et al., 2007) and minimized soil temperature fluctuations and improved crop root systems. The larger rooting systems in straw-mulched maize can take up more water and nutrients ultimately improving GY and WUE. However, reduced soil temperatures with straw mulching are a concern in areas 


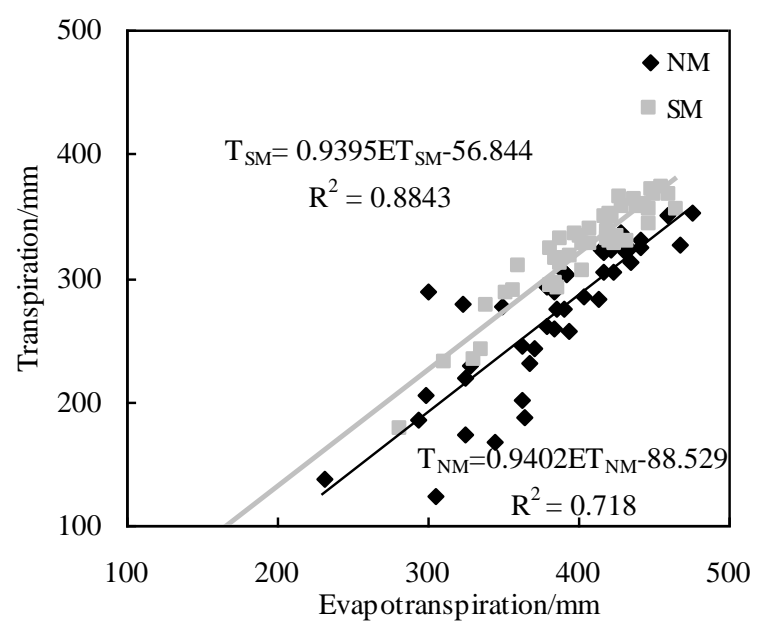

Fig.7: The relationship between multi-year evapotranspiration and transpiration with and without straw-mulched maize

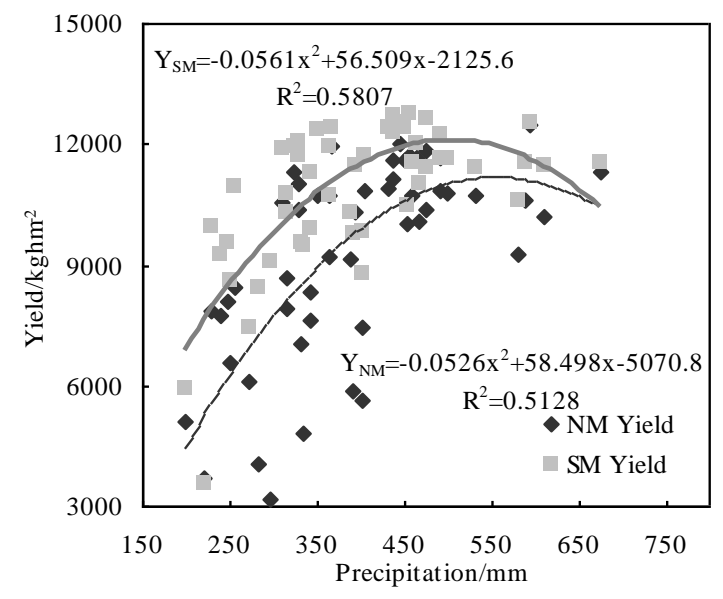

Fig. 8: The relationship between multi-year maize yield and precipitation

with cool springs during seedling emergence. Different climatic regions were different in straw mulching soil temperature. Straw mulching increased topsoil temperature in the winter wheat region (Zhang et al., 2014). In the sandy and semi-arid region of the west Liaoning province of China, straw-mulched maize field can decrease the $5 \mathrm{~cm}$ depth soil temperature $2.8^{\circ} \mathrm{C}$ before the maize tasseling stage. The results are similar to the previous results (Yun et al., 2006; Hari et al., 2012; Li et al., 2011; Wang et al., 2011). However, in winter-wheat with summer maize rotation system straw-mulched maize can increase the yield but reduced wheat yieldx (Zhou et al., 2011), which was attributed to reduced soil temperatures and delayed wheat growth in early spring (Dong et al., 2008) when minimizing soil temperature fluctuations during summer favoring maize yield formation. Straw mulching is regarded as a suitable way of improving water retention in the soil and reducing soil evaporation in sandy and semi-arid area (Zhang et al., 2009).

Numerous studies have shown that AquaCrop model has a wide range of applicability however, AquaCrop was designed at the beginning can overlook the soil water change caused by soil surface mulching management, which led to the deficiency of soil temperature in the AquaCrop model. Simulation of crop straw mulching process by AquaCrop model should be required to implement. Therefore, we quantified the inter-conversion effect between the cumulative soil temperature and the cumulative air temperature base on GDD. Modified air temperature of mulched-straw maize can input the weather module of AquaCrop model and then AquaCrop model can be used to simulate the maize mulch-saving water process (Fig. 2). The effective cumulative air temperature compensation values of different areas and crops were calculated by using this method. Because the GDD is the main parameter of the crop in this model, its adjustment is closely related to the growth and development characteristics of the cultivated maize varieties. Adjusted GDD parameters were based on the measured value of mulching maize and bare land maize in 2011-2013, which was adjusted depended on different crops and varieties (Table 1). Compared with other crop models AquaCrop model can be good at simulating crop evapotranspiration, crop transpiration and soil evaporation. The results showed that there was no significant difference in crop water consumption between two years compared with bare land, which was similar to that of measured results (Wang et al., 2014). But the composition of crop evapotranspiration has changed, which the average crop transpiration increased by $50.05 \mathrm{~mm}(20.5 \%)$ and soil evaporation decreased by $45.55 \mathrm{~mm}(37.9 \%)$. If crop transpiration under mulching would be measured through field method the AquaCrop model parameters (crop transpiration and water production efficiency etc) can be to further optimize and verify.

\section{Conclusion}

We conclude the combining AquaCrop model with recalculating air temperature of straw-mulched maize the AquaCrop model was suitable used to simulate crop evapotranspiration and yield under rainfed condition in the northeast sandy and semi-arid regions of China. The mean soil $(5 \mathrm{~cm}$ depth) temperature under straw-mulching was $2.8^{\circ} \mathrm{C}$ lower than without mulching before the maize tasseling stage. The recalculated air temperature of the straw-mulched maize $\left(\mathrm{T}_{\text {air-SM }}\right)$ together with verification and calibration of the AquaCrop model were considered based on the quantitative linear relationship between the $5 \mathrm{~cm}$ depth soil temperature and the air temperature of straw mulching. Therefore, the calibrated AquaCrop model with recalculating $\mathrm{T}_{\text {air-SM }}$ can accurately simulate water productivity of the straw-mulched maize in sandy and semiarid regions. Furthermore, there was the quantification of 
transpiration and the evapotranspiration of the linear relationship the nonlinear relationship between the maize yield and the precipitation was estimated and fitted by the calibration of the AquaCrop modeling. The maximum potential grain yields both SM and NM responses to precipitation and precipitation use efficiency was $503.6 \mathrm{~mm}$, $1.60 \mathrm{~kg} \mathrm{~m}^{-3}$ and $556.1 \mathrm{~mm}, 1.34 \mathrm{~kg} \mathrm{~m}^{-3}$. Finally, these results implicated that the developed AquaCrop model can be applied to the same sandy and semi-arid regions, as well as the simulated straw-mulched maize yield in response to water and temperature limiting factors under future climate change.

\section{Acknowledgements}

This work was supported by the National Natural Science Foundation of China (No 31501269); the National Science and Technology Support Project of China (No. 2012BAD09B02, No. 2014BAD12B04); Special Scientific Research Fund of Agricultural Public Welfare Profession of China (No.201303125, No.201503119) and Natural Science Foundation of Liaoning Province China (2014027021).

\section{References}

Abedinpour, M., A. Sarangi, T.B.S. Rajput, M. Singh, H. Pathak and T. Ahmad, 2012. Performance evaluation of AquaCrop model for maize crop in a semi-arid environment. Agric. Water Manage., 110: 55-56

Acharya, C.L., K.M. Hati and K.K. Bandyopadhyay, 2005. Mulches. In: Encyclopedia of Soils in the Environment, pp: 521-532. Hillel, D., C. Ro-senzweig, D.S. Pawlson, K.M. Scow, M.J. Sorger, D.L. Sparks and J. Hatfield (eds.). Elsevier Publication

Cai, T.Y., Z.K. Jia, L. Meng, F.Q. Guo, B.P. Yang, Y.W. Huang and X.L. Ren, 2011. Effects of different rates of straw mulch on soil moisture and yield of spring maize in Weibei Highland area of China. Trans. CSAE, 27: 43-48

Diepen, C.V., J. Wolf, H.V. Keulen and C. Rappoldt, 2007. WOFOST: a simulation model of crop production. Soil Use Manage., 5: 16-24

Dong, H., W. Li, W. Tang and D. Zhang, 2008. Furrow seeding with plastic mulching increases stand establishment and lint yield of cotton in a saline field. Agron. J., 100: 1640-1646

Du, W.Y., X.K. He, Z. Shamaila, Z.F. Hu, A.J. Zeng and J. Muller, 2011. Yield and biomass prediction testing of AquaCrop model for winter wheat. Trans. CSAM, 42: 174-178

Edwards, L., J.R. Burney, G. Richter and A.H. Macrae, 2000. Evaluation of compost and straw mulching on soil-loss characteristics in erosion plots of potatoes in Prince Edward Island, Canada. Agric. Ecosyst. Environ., 81: 217-222

Farahani, H.J., G. Izz and T.Y. Oweis, 2009. Parameterization and evaluation of the AquaCrop model for full and deficit irrigated cotton. Agron. J., 101: 469-476

Gao, Y.J. and S.X. Li, 2005. Cause and mechanism of crop yield reduction under straw mulch in dry land. Trans. CSAE, 21: 15-19

Hari, R., S. Yadvinder, K.S. Saini, D.S. Kler, J. Timsina and E. J. Humphreys, 2012. Agronomic and economic evaluation of permanent raised beds, no tillage and straw mulching for an irrigated maize-wheat system in northwest Indian. Exp. Agric., 48: 21-38

Hassan, F.U., M. Ahmad, N. Ahmad and M.K. Abbasi, 2007. Effects of subsoil compaction on yield and yield attributes of wheat in the subhumid region of Pakistan. Soil Till. Res., 96: 361-366

Heng, L.K., T. Hsiao, S. Evett, T. Howell, P. Steduto, 2009.Validating the FAO AquaCrop model for irrigated and water deficient field maize. Agron J., 101: 488-498
Hoshino, A.T., F.T. Hata, G.S.D. Aquino, A.D.O.M. Junior, M.U. Ventura and C.D.C. Medina, 2017. Mulching with sugarcane straw reduces weed density in sugarcane field. Int. J. Agric. Biol., 19: $121-124$

Hsiao, T.C., L. Heng, P. Steduto, B.R. Lara, D. Raes and E. Fereres, 2009. Aqua Crop-model parameterization and testing for maize. Agron. J., 101: 448-459

Huang, G.B., Q.Y. Guo, R.Z. Zhang, L. Pang, L. Guangdi, Y.C. Kwong and A.Z. Yu, 2006. Effects of conservation tillage on soil moisture and crop yield in a phased rotation system with spring wheat and field pea in dryland. Acta Ecol. Sin., 26: 1176-1185

Joost, W., R. Dirk, T. Farid, A. Denis, B. Djaby and B. Tychon, 2013. Performance assessment of the FAO AquaCrop model for irrigated cabbage on farmer plots in a semi-arid environment. Agric. Water Manage., 127: 40-47

Li, C.Y., L. Ren and B.G. Li, 2000. Advances in simulating studies on water, heat, and salt movement in soils with straw mulch. Adv. Water Sci., 11: 325-332

Li, Y.X., B. Zhang and Y.X. Wei, 2011. Effects of straw mulching on ground temperature and growth relationship of maize. J. Irri. Drain., 30: $82-85$

Margarita, G. and F. Elias, 2012. Combining the simulation crop model AquaCrop with an economic model for the optimization of irrigation management at farm level. Eur. J. Agron., 36: 21-31

McCown, R., G. Hammer, J. Hargreaves, D. Holzworth and D. Freebairn, 1996. APSIM: a novel software system formodel development, model testing and simulation in agricultural systems research. Agric. Sys., 50: 255-271

Mubeen, M., A. Ahmad, A. Wajid, T. Khaliq and A. Bakhsh, 2013. Evaluating CSM-CERES-Maize model for irrigation scheduling insemi-arid conditions of Punjab, Pakistan. Int. J. Agric. Biol., 15: 110

Nash, J.E. and J.V. Sutcliffe, 1970. River flow forecasting through conceptual models. I. A discussion of principles. J. Hydr., 10: 282 290

Steduto, P., T.C. Hsiao, D. Raes and E. Fereres, 2009. AquaCrop-the FAO crop model to simulate yield response to water: I. Concepts and underlying principles. Agron. J., 101: 426-437

Stöckle, C.O., M. Donatelli and R. Nelson, 2003. CropSyst, acropping systems simulation model. Eur. J. Agron., 18: 289-307

Timsina, J., D. Godwin, E. Humphreys, Y. Singh, B. Singh, S.S. Kukal and D. Smith, 2008. Evaluation of options for increasing yield and water productivity of wheat in Punjab, India-using the DSSAT-CSMCERES-Wheat model. Agric. Water Manage., 95: 1099-1110

Todorovic, M., R. Albrizio, L. Zivotic, M.T. A. Saab, C. Stöckle and P. Steduto, 2009. Assessment of Aqua Crop, Crop Syst, and WOFOST models in the simulation of sunflower growth under different water regimes. Agron. J., 101: 509-521

Wang, K.X., Q. Fu, X. Jiang and X.P. Zhang, 2014. Effect of straw mulching mode on maize physiological index and water use efficiency. Trans. CSAM, 45:181-186

Wang, M., H.X. Wang, Q.F. Han, R. Li, R. Zhang, Z.K. Jia and B.P. Yang, 2011. Effects of different mulching materials on soil water, temperature, and maize growth. Acta Agron. Sin., 37: 1249-1258

Wang, X.X., Q.J. Wang, J. Fang and Q. Fu, 2013. Evaluation of the AquaCrop model for simulating the impact of water deficits and different irrigation regimes on the biomass and yield of winter wheat grown on China' Loess Plateau. Agric. Water Manage., 129: 95-104

Willmott, C.J., G.S. Akleson, R.E. Davis, J.J. Feddema, K.M. Klink, D.R. Legates, J. Odonnell and C.M. Rowe, 1985. Statistic for the evaluation and comparison of models. J. Geophys. Res., 90: 88959005

Wu, C.L., J.S. Huang and R.K. Shen, 2000. A model of heat and water flow in SPAC under transparent polyethylene mulch. J. Hydr. Eng., 11: $89-96$

Xiao, M., J.P. Zhong and L. Zhao, 1998. Studies on the correlation between cotton soil temperatureand airtemperature, and the compensating action of soil temperature increase in the mulched cotton field on effective air accumulation temperature. J. XinJiang Agric. Uni., 21: 257-261 
Yang, N., Z.X. Sun, L.S. Feng, M.Z. Zheng, D.C. Chi, W.Z. Meng, Z.Y. Hou, W. Bai and K.Y. Li, 2015. Plastic film mulching for water-wfficient agricultural applications and degradable films materials development research. Mater. Manuf. Proc., 30: 143-154

Yun, X.F., P.T. Wu, Y.K. Wang and F.L. Xu, 2006. Soil moisture conserving irrigation under straw mulch with no-tillage. Trans. CSAE, 22: 22-26

Zhang, L.Z., W.V.D Werf, W. Cao, B. Li, X. Pan and J.H.J. Spiertz, 2008. Development and validation of SUCROS-Cotton a potential crop growth simulation model for cotton. NJAS-Wageningen J. Life Sci., 56: $59-83$

Zhang, L.Z., W.X. Cao, S.P. Zhang and W.H. Luo, 2003. Simulation model for cotton development stages based on physiological development time. Acta Gossypii Sin., 15: 97-103

Zhang, S.L., L. Lövdahl, H. Grip, Y.A. Tong, X.Y. Yang and Q.J. Wang, 2009. Effects of mulching and catch cropping on soil temperature, soil moisture and wheat yield on the Loess Plateau of China. Soil Till. Res., 102: 78-86
Zhang, W.H., W.Z. Liu, Q.W. Xue, J. Chen and X.Y. Han, 2013. Evaluation of the AquaCrop model for simulating yield response of winter wheat to water on the southern Loess Plateau of China. Water Sci. Technol., 68: 821-828

Zhang, Y.C., S.X. Chai, Y.D. Fan, H.B. Cheng, C.X. Huang, K.M. Tan, L. Chang and C.G. Yang, 2014. Effects of mulching models on soil temperature and yield of winter wheat in rainfed area. Chin J. AgroMeteorol., 35: 403-409

Zhou, J.B., C.Y. Wang, H. Zhang, F. Dong, X.F. Zheng, W. Gale and S.X. $\mathrm{Li}, 2011$. Effect ofwater saving management practices and nitrogen fertilizer rate on crop yield and wateruse efficiency in a winter wheat-summer maize cropping system. Field Crops Res., 122: 157163

(Received 17 April 2017; Accepted 25 May 2017) 